\title{
Comparison of the inherent variability in rebound hammer tests performed with different testing instruments
}

KATALIN SZILÁGYI - PhD candidate, BME, Dept. of Construction Materials and Engineering Geology - szilagyikt@gmail.com

AdORJÁn BOROSNYÓI - Assoc. Prof., BME, Dept. of Construction Materials and Engineering Geology - adorjan.borosnyoi@gmail.com

TAMÁs MIKÓ - BSc candidate, BME, Dept. of Construction Materials and Engineering Geology

- miko.tomi.92@gmail.com

Érkezett: 2013. 10. 18. - Received: 18. 10. 2013. - http://dx.doi.org/10.14382/epitoanyag-jsbcm.2013.14

\section{Abstract}

The rebound hammer test of concrete can provide an alternative to drilled core tests for estimating the in-situ compressive strength of concrete. The variability of concrete strength is recognised during the strength assessment and the design strength of concrete is specified as its characteristic compressive strength by taking the variability of the strength of concrete into account. In the present paper, particular topics of the inherent variability of the rebound hammer tests are discussed. Different types of Schmidt hammers are compared in this sense. The precision of the original N-type Schmidt hammer is demonstrated to be superior to original L-type or Silver Schmidt N-type hammers. Observations are confirmed by normality tests. Results imply the need for further research. Measurement errors made by the operators of the rebound hammers are analysed. Differences among the repeatability and reproducibility are demonstrated. As a closing remark the need of revealing the connection between the variability of compressive strength and rebound index, as well as the need of the spatial variability analysis of rebound index are highlighted.

Keywords: concrete, rebound hardness, Schmidt hammer, inherent variability, repeatability, reproducibility

\section{Introduction}

The variability of concrete strength is recognised during the strength assessment and the design strength of concrete (as characteristic compressive strength) is specified by taking the variability of the strength of concrete into account.

During in-situ testing, the most significant characteristic of the non-destructive tests is that the compressive strength of the concrete is not measured directly in a structure.

Variability can be considered in different ways by different statistical parameters, however, two levels of variability can be attributed to the rebound hammer test: 1) the inherent variability corresponding to one test location and being influenced by the measurement uncertainties (operator and testing device) and the local inhomogeneity of the concrete, and 2) the spatial variability that indicates the measure of the dissimilarity of the inherent variability for different test locations. In the present paper, particular topics of the inherent variability of the rebound hammer tests are discussed.

\section{Method}

The rebound hammer appeared in the 1950's and the rebound hammer test is the most widespread method for the surface hardness testing of concrete.

The rebound hammer (i.e. a tailored spring impact hammer; Fig. 1.) was developed in Basel, Switzerland by Ernst Schmidt [1]. The hardness testing method of Shore [2] was adopted in the device, and the measure of surface hardness is the rebound index. The method became popular very fast as the rebound index can be read directly on the scale of the device and no measurements on the concrete surface are needed [3]. The original idea and design of the device was further developed in 1952 (using one impact spring instead of two) resulted in simpler use [4,5]. In 1954 Proceq $S A$ was founded and has been producing the original Schmidt rebound hammers since then, without any significant change in the operation of the instrument [6]. One of the latest developments of the rebound hammers was finalized in November 2007, since the Silver Schmidt hammers are available [7]. The digitally recording Silver Schmidt hammers recorded formerly the original Schmidt rebound index as well, not only the coefficient of restitution (referred as Q-value) of concrete. From 2011, however, the Silver Schmidt hammers are no more instrumented to record the original Schmidt rebound index. Only the Q-value is measurable.

With this skip, the direct relationship between the two hardness values can not be compared any more, and the long-

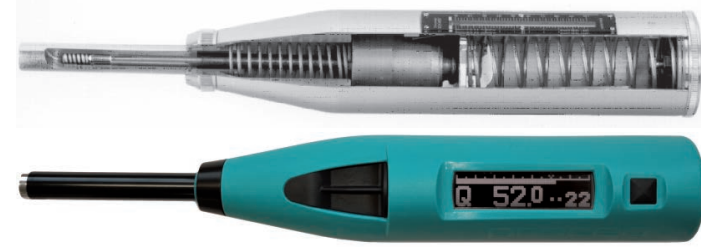

Fig. 1. Original Schmidt rebound hammer and Silver Schmidt rebound hammer 1. ábra Az eredeti Schmidt kalapács és a Silver Schmidt kalapács 
term experience with the original rebound hammers, thus the considerable amount of rebound index data can not be used. That can be considered as a drawback from a scientific point of view.

\section{Sources of variability and terminology (accuracy, bias, systematic error, random error, repeatability, reproducibility)}

During testing, even when none of the experimental parameters is intentionally changed, small changes usually occur both in strength and hardness measurements. These changes are realised as variability among the measured values. Some of the more common (potential) sources of variability during in-situ testing are the operator (performance influences), the testing device (condition and calibration), the environment (temperature, etc.), the test location (heterogeneity of the material). The variability may include systematic components (bias) and random components (error). The systematic components may be eliminated by correct calibration of the testing device by a reference material.

In statistics, sampling bias/sampling error is a deviated sampling when the sample is collected in such a way that some members of the population are less likely to be included than others. Problems with sampling are expected when data collection is entrusted to subjective judgement of human [8]. An example is the systematic error of an observer. Systematic errors are very difficult to deal with, because their effects are only observable if they can be removed, but usually they cannot be removed by e.g. increasing the sample size. Random errors have zero expected value (scattered about the true value) and tend to have zero mean value when a measurement is repeated. Random errors can be attributed either to the testing device or to the operator. The accuracy of statistical information is the degree to which the information correctly describes the phenomena that is intended to be measured [8].

According to the ISO 3534-1 International Standard [9] the repeatability is the precision under conditions where independent test results are obtained with the same method on identical test items in the same laboratory by the same operator using the same equipment within short intervals of time. Generally speaking, repeatability shows that how can a person repeat his measurement in the future similarly to that of he did in the past. Therefore, repeatability is the spread of measurements made under the repeatability conditions (=measurement variability by the same operator). More specifically, repeatability is a number that is unlikely to be exceeded by the difference between two measurements made under the repeatability conditions.

According to the ISO 3534-1 International Standard [9] the reproducibility means the precision under conditions where test results are obtained with the same method on identical test items in different laboratories with operators using different equipment. Generally speaking, reproducibility shows that how can a person reproduce a measurement in the future similarly to that was made by another person in the past. Therefore, reproducibility is the additional spread within measurements made under the reproducibility conditions (=additional measurement variability by different operators). More specifically, reproducibility is a number that is unlikely to be exceeded by the difference between two measurements made under reproducibility conditions.

There are different considerations as well. In the nomenclature of e.g. ACI 228.1R-03 Committee Report "In-Place Methods to Estimate Concrete Strength" repeatability is referred as within-test variation and reproducibility is referred as batchto-batch variation [10]. Also, repeatability is sometimes called equipment variation and reproducibility is called appraiser variation [11].

According to the ISO 5725-1 International Standard [12] the accuracy of a measurement is described by the trueness (=proximity of measured values to the true value) and the precision (=either repeatability or reproducibility of the measurement) together. Different accuracies are indicated schematically in Fig. 2.

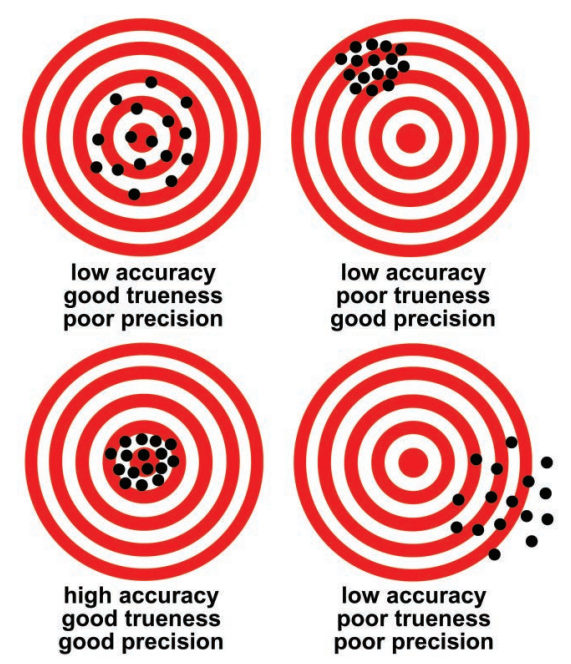

Fig. 2. Schematic representation of accuracy by trueness and precision

2. ábra A pontosság sematikus illusztrációja a valódiság és a precizitás fogalmaival

The uncertainty of the average value of the rebound hammer test reading (either $\mathrm{R}$ or $\mathrm{Q}$ ) depends on three influences: 1) the variability of the strength of concrete in the structure; 2 ) the repeatability of the rebound hammer test; 3 ) the number of individual readings [10].

\section{Precision statements about the rebound index}

The ASTM C 805 International Standard contains precision statements for the rebound index of the rebound hammers [13]. It is given for the precision that the within-test standard deviation of the rebound index is 2.5 units, as "single-specimen, single-operator, machine, day standard deviation". Therefore, the range of ten readings should not exceed 12 units (taking into account a $\mathrm{k}=4.5$ multiplier given in ASTM C 670[14]). Dependence of the within-test standard deviation on the average rebound index is not indicated. Particular literature data support the ASTM C 805 suggestions, e.g. [15].

For the bias of the rebound hammer test no evaluation is given in the ASTM C 805 standard [13]. It is indicated that the rebound index can only be determined in terms of this test method, therefore, the bias can not be evaluated. 


\section{Precision statements about the compressive strength}

The precision of the concrete compressive strength test results is discussed in EN 12390-3 European Standard [16] in terms of repeatability and reproducibility conditions, based on the compressive strength experiments, in which 1) the measurement data include the uncertainties of sampling, specimen preparation, curing and compressive strength test; 2 ) the measurements were carried out on $100 \mathrm{~mm}$ and $150 \mathrm{~mm}$ cube specimens. The precision data were determined in the UK in 1987; the concretes were made using an ordinary Portland cement, Thames Valley sand, and Thames Valley coarse aggregates. Hand compaction was used. The ratio of the range and the standard deviation is 2.77 in case of the repeatability, as well as the reproducibility conditions, accordingly the result of two measurements $(\mathrm{n}=2)$ was evaluated (Table 1 ).

\begin{tabular}{|c|c|c|c|c|}
\hline \multirow[t]{2}{*}{$\begin{array}{l}\text { Specimen } \\
\text { type and size }\end{array}$} & \multicolumn{2}{|c|}{$\begin{array}{c}\text { Repeatability } \\
\text { conditions }\end{array}$} & \multicolumn{2}{|c|}{$\begin{array}{l}\text { Reproducibility } \\
\text { conditions }\end{array}$} \\
\hline & $s / f_{c m}, \%$ & $\mathbf{r} / \mathbf{f}_{\mathrm{cm}}, \%$ & $\mathrm{~s} / \mathrm{f}_{\mathrm{cm}}, \%$ & $r / f_{c m}, \%$ \\
\hline $100 \mathrm{~mm}$ cubes & 3.2 & 9.0 & 5.4 & 15.1 \\
\hline $150 \mathrm{~mm}$ cubes & 3.2 & 9.0 & 4.7 & 13.2 \\
\hline $\begin{array}{r}\text { Table 1. Precision } \\
\text { concrete, } \\
\text { whose di }\end{array}$ & \multicolumn{4}{|c|}{$\begin{array}{l}\text { Precision data for measurements of the compressive strength of hardened } \\
\text { concrete, expressed as percentages of the mean of the two cube strengths } \\
\text { whose difference is to be compared with repeatability or reproducibility [16] }\end{array}$} \\
\hline $\begin{array}{l}\text { 1. táblázat Megszilá } \\
\text { két kocka } \\
\text { hatósági }\end{array}$ & \multicolumn{4}{|c|}{$\begin{array}{l}\text { Megszilárdult beton nyomószilárdsági vizsgálat precizitásának megadása } \\
\text { két kocka nyomószilárdság vizsgálata alapján ismételhetőségi és reprodukál- } \\
\text { hatósági feltételek esetén [16] }\end{array}$} \\
\hline
\end{tabular}

It is indicated that the difference between two test results from the same sample by one operator using the same apparatus within the shortest feasible time interval will exceed the repeatability value on average $\left(\mathrm{r} / \mathrm{f}_{\mathrm{cm}}=9 \%\right.$ in case of $150 \mathrm{~mm}$ cube) not more than once in 20 cases (5\%) in the normal and correct operation of the test method.

It is also indicated that the difference between the test results on the same sample obtained within the shortest feasible time interval by two operators each using their own apparatus will exceed the reproducibility value on average $(\mathrm{r} / \mathrm{f} \mathrm{cm}=13.2 \%$ in case of $150 \mathrm{~mm}$ cube) not more than once in 20 cases (5\%) in the normal and correct operation of the test method.

Further information on precision, and for definitions of the statistical terms used in connection with precision can be found in ISO 5725-1 International Standard [12].

\section{Comparison of different types of rebound hammers}

\subsection{Variability of the different rebound indices}

The very robust design of the original Schmidt hammers provide full protection to the mechanical parts by a sturdy metal housing. The calibration and maintenance is simple. If the maintenance of the instrument is regular and its moving parts are kept clean, then failure and erroneous operation can only be expected if the operator is unskilled or not careful and implements a very severe operational error. The original Schmidt hammers record the rebound index (R): the ratio of paths driven by the hammer mass during rebound and before impact; see Eq. (1).
$R=\frac{x_{r}}{x_{0}} \cdot 100$

where $x_{0}$ indicates the path driven by the hammer mass before impact, and $x_{r}$ indicates the path driven by hammer mass after impact, respectively.

The Silver Schmidt hammer - the competitor of the original Schmidt hammer - has some operational differences. The mechanical components of the device are operated, except for a few modifications (e.g. the hammer mass has lower weight than that of the original design), by the same principle as the original instruments. However, in the Silver Schmidt hammer the velocity of the hammer mass is measured by optical measuring transformer. The light is modulated by the grooves on the circumference of the hammer mass and transmitted to a photodiode. The duration of the impact/rebound periods is expressed by the ratio of the velocities. The result of the velocity measurement is not influenced by the gravitation (so the rebound value requires no angular correction). As the hammer mass of the Silver Schmidt hammer is of less weight, it runs the forth and back paths quicker. The weight of the plunger of the device is also smaller than that of the original Schmidt hammer. Therefore, and also due to the different measuring method, the $\mathrm{Q}$ value of the Silver Schmidt hammer is greater than the $\mathrm{R}$ value of the original Schmidt hammer. The Q-value represents the ratio of kinetic energies of the hammer mass right after and just before the impact ( $\mathrm{E}_{0}$ and $\mathrm{E}_{\mathrm{r}}$, respectively); see Eq. (2).

$Q=\frac{E_{r}}{E_{0}} \cdot 100=\frac{v_{r}^{2}}{v_{0}^{2}} \cdot 100$

where $v_{0}$ indicates the velocity reached by hammer mass before impact, and $v_{r}$ indicates the velocity reached by hammer mass after impact, respectively.

The first generation of the Silver Schmidt hammers was implemented to record both $\mathrm{R}$ and $\mathrm{Q}$ values. Manufacturer Proceq SA provided the devices with the conversion curve represented in Fig. 3 [7]. The second generation of the Silver Schmidt hammers, however, does not record the $\mathrm{R}$ values. According to the manufacture's opinion, no relationship is suggested between the $\mathrm{Q}$ and the $\mathrm{R}$ rebound values [17].

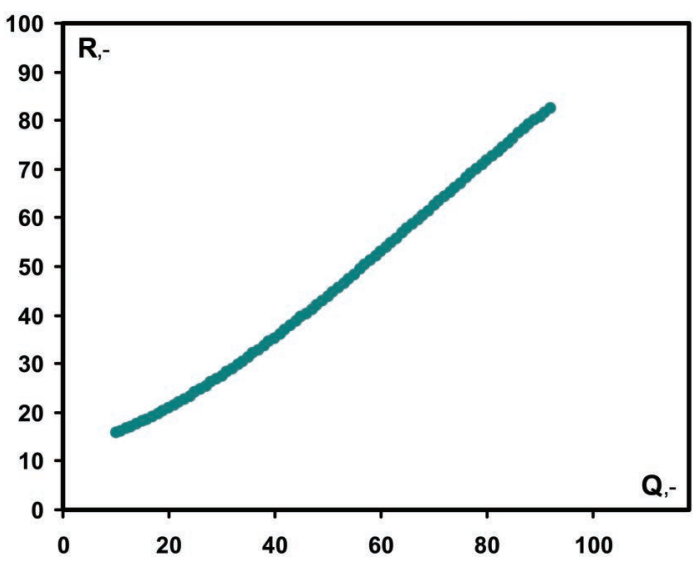

Fig. 3. Relationship between rebound index $R$ and rebound index $Q$ [7] 3. ábra AzR és a Q visszapattanási érték kapcsolata [7] 
This is noteworthy for several reasons. On the one hand, previous experience of many years applies to the original $\mathrm{R}$ rebound values. Practically no data are available in the technical literature related to the new devices. The standards also formulate guidelines for the original Schmidt hammers. On the other hand, the changes in the operating and measuring principle raise questions concerning the repeatability and reproducibility: does the new device provide similar measurement uncertainty than that of the original Schmidt hammer or does show better or less favourable performance?

In this respect, very limited number of references can be found in the technical literature, and the experiences are not favourable so far.

It has been shown on 10 different natural stones that the necessary sample size to arrive at the same confidence level of the estimation of the sample mean is considerably higher for the Silver Schmidt hammer than is needed for the original Schmidt hammer, regardless the magnitude of the operator observational error [18]. The digital data collection for the Q value (Silver Schmidt hammer) instead of the operator's eye sensory reading for $\mathrm{R}$ value (original Schmidt hammer) does not improve the precision of the measurement. This clearly indicates that the measurement uncertainties, i.e. the repeatability parameters of Silver Schmidt hammer are less favourable than that of its predecessor. It calls the attention to further analyses.

A comparative study of four different rebound indices was performed by laboratory testing on 11 individual, identical concrete cubes of $150 \mathrm{~mm}$. The testing devices were an L-type original Schmidt hammer, an N-type original Schmidt hammer and a first generation Silver Schmidt hammer capable to record both $\mathrm{R}$ values and $\mathrm{Q}$ values. Table 2 summarizes test results. 20 rebound index recordings were taken by each device on each specimen. It can be seen that the highest precision corresponds to the $\mathrm{N}$-type original Schmidt hammer (highest precision means here the lowest range and the lowest standard deviation for the measured values at individual test locations). Lower precision of the L-type original Schmidt hammer and of the Silver Schmidt hammer is due to the lighter hammer masses impacting within both devices and the sensitivity of the electro-optical recording (Silver Schmidt hammer).
It can be observed in Fig. 4 as well, that the rebound indices can be recorded at a larger uncertainty in case of lower impact energy: the standard deviation and the coefficient of variation of the rebound indices of the L-type original rebound hammer is larger than that of the $\mathrm{N}$-type original rebound hammer. Moreover, it can be realized that the electro-optical recording of the Silver Schmidt hammer involves considerable uncertainty: the uncertainty of the Q value is about $20 \%$ larger and the uncertainty of the $\mathrm{R}$ value is $50-60 \%$ larger than that of the $\mathrm{R}$ value provided by the original $\mathrm{N}$-type rebound hammer. Fig. 4 is based on the average standard deviation and average coefficient of variation of the 11 cubes of the same concrete composition $\left(\mathrm{f}_{\mathrm{cm}}=64.7 \mathrm{~N} / \mathrm{mm}^{2}, \mathrm{R}_{\mathrm{Nm}}=42.13\right)$.
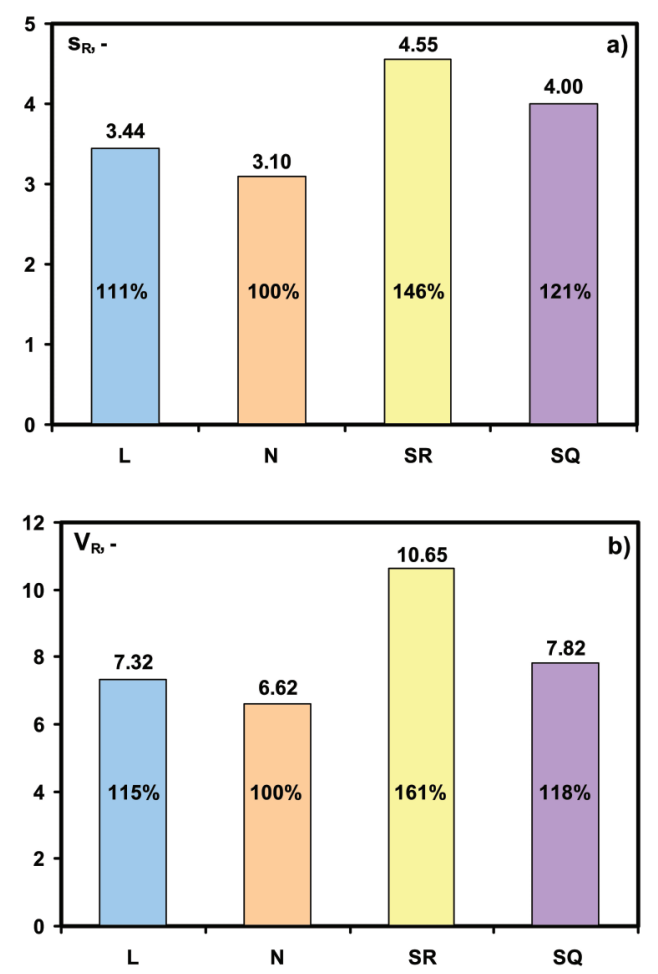

Fig. 4. Comparison of a) the standard deviation and $b$ ) the coefficient of variation of different rebound indices

4. ábra Különböző visszapattanási értékek statisztikai jellemzőinek összehasonlitása a) szórás és b) relatív szórás

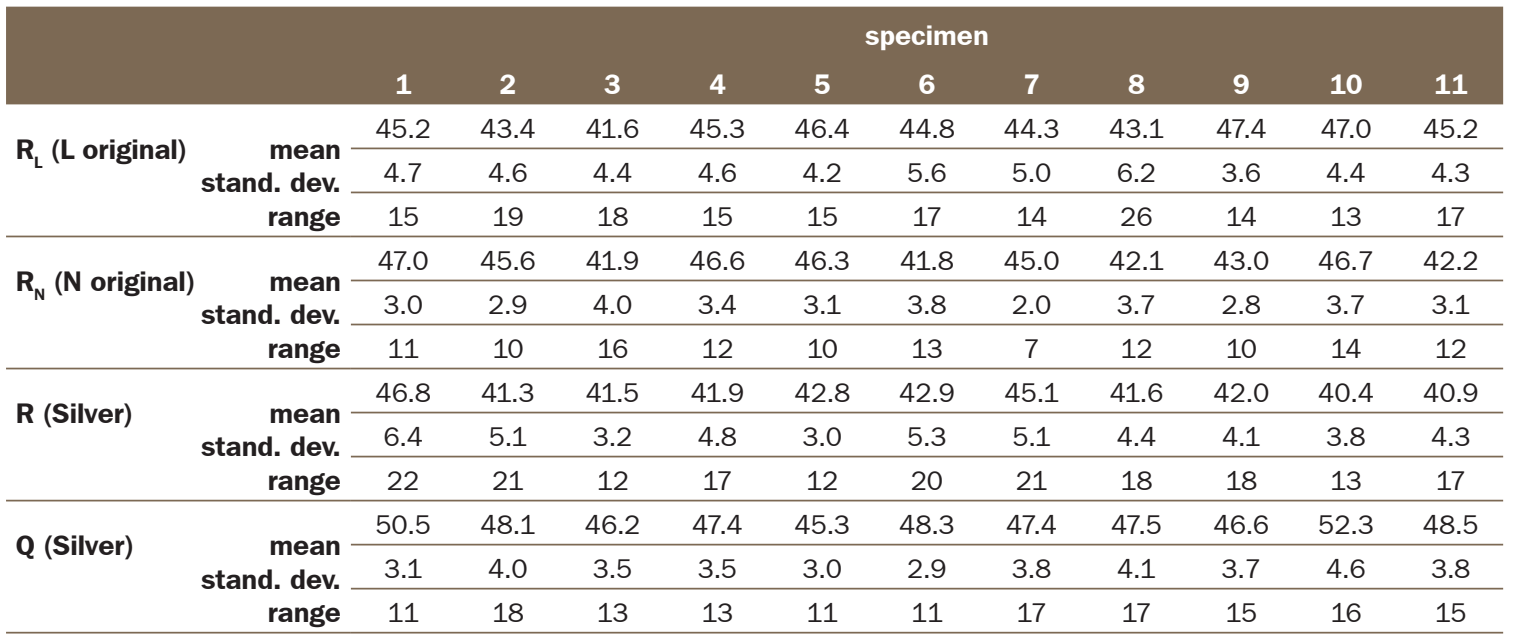

Table 2. Statistical characteristics of rebound indices obtained by different types of rebound hammers [19]

2. táblázat Különbözö visszapattanási értékek statisztikai jellemzőinek összehasonlitása [19] 
The observations may also serve to explain in parts why the manufacturer has terminated the recording of the $\mathrm{R}$ value in the second generation of the Silver Schmidt hammers. It is acceptable that such unreliable performance is not used for hardness parameter determination that could provide large measurement uncertainty to the user. Inferior precision of the $\mathrm{Q}$ value reading compared to that of the original Schmidt rebound index is still need to be analysed further.

Another open issue is that in-situ measurements of the $Q$ value can not be related to the earlier experiences of more decades and, therefore, the user performing the strength estimation could rely only on the strength estimation relationships of the manufacturer company (which is not a scientific research institute) and which strength estimation curves are formulated on the basis of limited scientific background and limited in-situ experience. The attention of material testing engineers should be called to these limits, because the strength estimation of a structural concrete of unknown composition is a challenge even with the original Schmidt hammers of good repeatability characteristics (it should be also emphasised here that the EN 13791:2007 European Standard [20] does not propose the use of any non-destructive method without drilled core samples).

The consequences of the increase in the inherent measurement uncertainty of the Silver Schmidt hammers by their design and development are topics for future research.

\subsection{Normality of the different rebound indices}

The normality tests are used in mathematical statistics to study if a data set has normal distribution or not. The normality tests can be useful for the rebound hammer tests since normality is a frequent presumption in statistical procedures. There are about 40 normality tests available in the technical literature [21], however, the most common normality test procedures of statistical analyses are the Shapiro-Wilk test, the KolmogorovSmirnov test, the Anderson-Darling test and the Lilliefors test. It is demonstrated in the technical literature that the ShapiroWilk test is the most powerful normality test from the above four [22]. An analysis is introduced here for the rebound hammer test based on the Shapiro-Wilk normality test.

It can be assumed for the rebound hammer test that the rebound index reading sets of separate test locations are independent and identically distributed (i.i.d.) random variables. It is expected that the probability distribution of the rebound index does not change by location within the same concrete structure and the independent test locations can be considered to be mutually independent. The central limit theorem can be considered acceptable for the rebound hammer test; i.e. the probability distribution of the sum (or average) of the rebound index reading sets of independent test locations (each with finite mean and finite variance) approaches a normal distribution if sufficiently large number of the i.i.d. random variables is available.

It can be demonstrated by the running of the Shapiro-Wilk normality test, whether the probability distribution of the rebound index reading sets of individual test locations can be described by normal distribution or not. The Shapiro-Wilk normality test can be considered as a practical application of the central limit theorem for the rebound index reading sets of individual test locations and, therefore, may be a good indicator for the precision of the rebound hammer test.

During the comparison, four different rebound indices were compared by the laboratory testing of 11 individual, identical concrete cubes of $150 \mathrm{~mm}$ (with average compressive strength of $f_{c m}=64.7 \mathrm{MPa}$ ) detailed above. The testing devices were an L-type original Schmidt hammer, an N-type original Schmidt hammer and a first generation Silver Schmidt hammer capable to record both $\mathrm{R}$ values and $\mathrm{Q}$ values. The Shapiro-Wilk normality test was run and the $\mathrm{W}$ statistic was calculated for 1 , $2,3, \ldots, 11$ rebound index reading sets combined.

Fig. 5 summarizes the values of the $\mathrm{W}$ statistic as a function of increasing number of specimens. It is demonstrated that values of W statistic approaches the fastest to unity for the N-type original Schmidt hammer. It implies its superior precision. The tendencies are similar for the L-type original Schmidt hammer, but the $\mathrm{W}$ statistic shows lower values. Results are controversial in the case of the Silver Schmidt hammer. Tendency of the values for the $\mathrm{W}$ statistic seem to decrease rather than increase, which contradicts probability theory and apparently indicates that the central limit theorem does not apply. The observed behaviour highlights again the concerns of the electro-optical data collection. The results, however, confirm the long term advantageous experiences with the N-type original Schmidt hammers (see e.g. [18] as well).
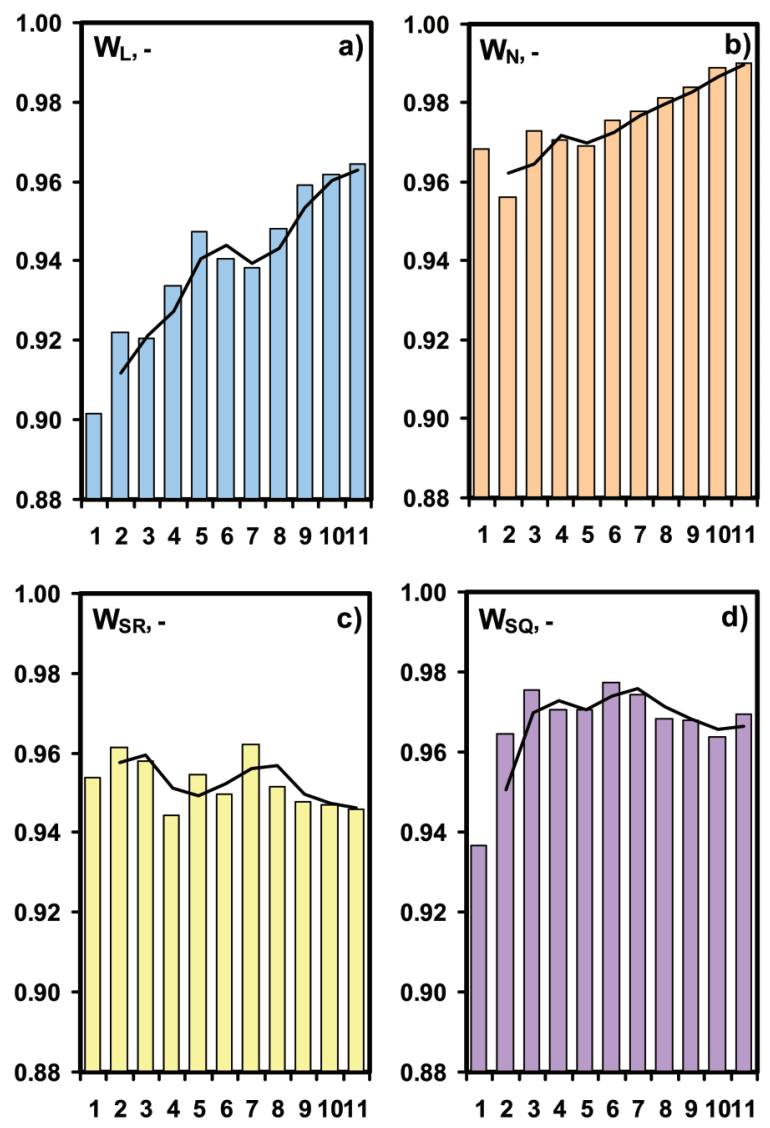

Fig. 5. Comparison of the Shapiro-Wilk test W statistic of different rebound indices a) L-type original Schmidt hammer, b) N-type original Schmidt hammer c) Silver Schmidt hammer $R$ values d) Silver Schmidt hammer $Q$ values

5. ábra A Shapiro-Wilk normalitás vizsgálat $W$ statisztikája különböző visszapattanási értékekre vonatkozóan a) L-típusú Schmidt kalapács b) N-típusú Schmidt kalapács c) Silver Schmidt kalapács R-érték d) Silver Schmidt kalapács Q-érték 


\subsection{Reproducibility of the rebound indices}

The concept of reproducibility of the rebound method includes the error produced by the operator as well. In this regard, three operators contributed in a reproducibility analysis presented here. Rebound hammer tests were carried out on $2 \times 3=6$ standard cube specimens of two different strength classes. The average concrete compressive strengths were $\mathrm{f}_{\mathrm{cm}, 1}=65.8 \mathrm{~N} / \mathrm{mm}^{2}$ (MIX1) and $\mathrm{f}_{\mathrm{cm}, 2}=89.7 \mathrm{~N} / \mathrm{mm}^{2}$ (MIX2). All the three operators recorded 20-20 individual readings on each specimen with both $\mathrm{N}$-type and L-type original Schmidt hammer. The results were evaluated by the type of concrete and per the operator, separately. It was realized - concerning the repeatability of measurements - that the standard deviation and the coefficient of variation of the rebound index is smaller in the case of the higher strength concrete (with higher average rebound index), independently of the operator. It was also observable that none of the three operators made performance errors during the measurements: the average rebound values recorded on the same concrete, by all three operators were almost identical; trueness of the measurements can be considered good in all cases. However, consequences can not be drawn for the reproducibility based on the average rebound indices. As a possible approximation, the standard deviations of the measurements and particular statistical parameters of the standard deviations were chosen for the comparison of uncertainty attributed to the operators. It was considered that an operator is accurate, if the standard deviation of the mean ${ }^{*}$ of the measurement is small, and an operator is precise if the standard deviation of the standard deviation ${ }^{*}$ of the measurement is small (* it is noted that mean is defined here as the arithmetic mean of individual rebound indices at a test location and standard deviation is defined here as the standard deviation of individual rebound indices at a test location). Strictly speaking, this concept does not meet the definition of accuracy and precision, but it is acceptable as an analogy if the average rebound values are considered as the true value, and the variation around this true value is analyzed. Thus, if the standard deviation of the individual measurements of an operator is small at a test location, it means that the readings are implemented in the narrow vicinity of the true value. And if the standard deviation of the standard deviation of the individual measurements of an operator is small considering multiple test locations, it means that the limit of the reading range around the true value varies in narrow vicinity. Evaluation of the test results are presented in Fig. 6.

Although the differences are not significant at all, but based on the above principles, the most accurate and most precise operator (operator 2), an accurate and less precise operator (operator 1), and the least accurate and least precise operator (operator 3) can be assigned. During the reproducibility studies it should always be evaluated separately that to which reasons the differences observable at the operators can be attributed and how the differences can be overcome by e.g. refining the testing skill. This is important by two reasons in case of the Schmidt hammer tests (even with a correctly calibrated device, i.e. with favourable repeatability parameters) because both operational error (incorrect handling and operation of the device) and observational error (incorrect reading on the scale of the device) can be implemented by the operators.
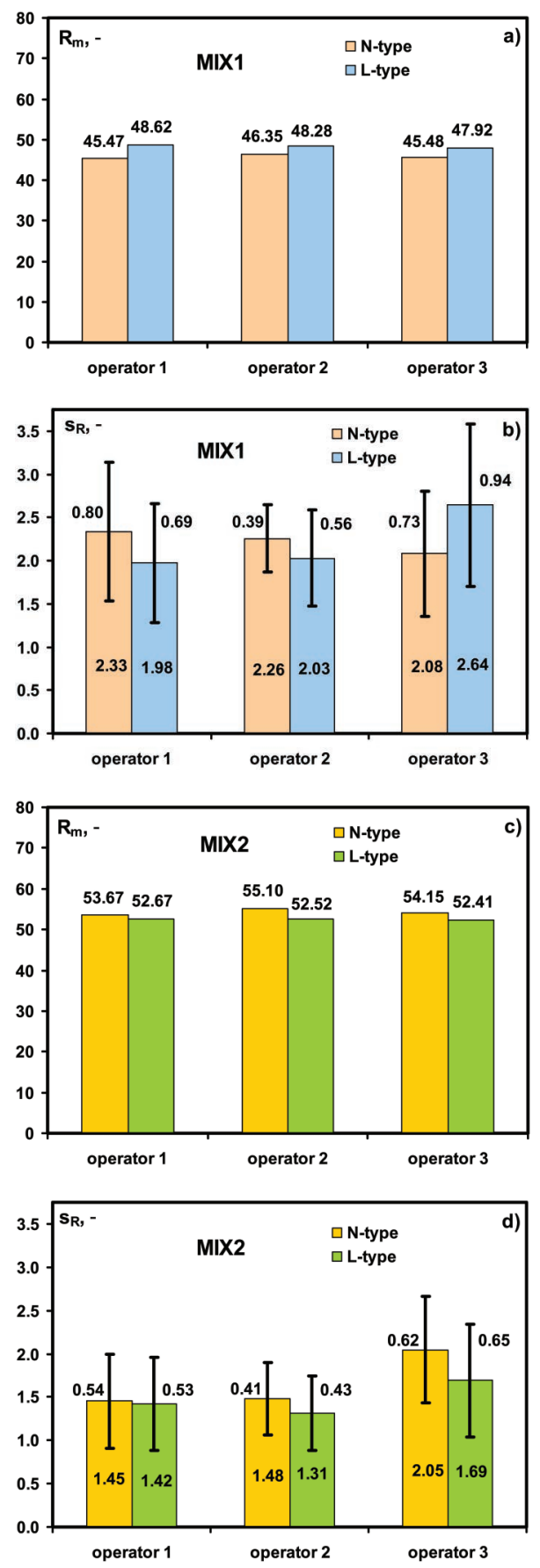

Fig. 6. Repeatability and reproducibility analysis of the rebound hammer test

6. ábra Ismételhetöségi és reprodukálhatósági jellemzök Schmidt kalapácsos vizsgálatra vonatkozóan

\section{Need for spatial variability analyses}

There is considerable interest, from a practical point of view, on a possible connection of the repeatability of in-situ measurements (e.g. the rebound hammer tests) and that of the compressive strength tests: namely, it is an open question if the coefficient of variation of the rebound index $\left(\mathrm{V}_{\mathrm{R}}\right)$ could be an acceptable estimate of the coefficient of variation of concrete compressive strength $\left(\mathrm{V}_{\mathrm{f}}\right)$. Reliability analyses need the value of $\mathrm{V}_{\mathrm{f}}$, however, it is time consuming and expensive to establish its value in a practical situation. Rebound hammer test, on the other hand, is easy to perform and may provide a far less time consuming and expensive solution in a practical situation. 
According to the EN 12390-3 European Standard [16], repeatability of strength is represented as the normalised range. It is demonstrated elsewhere [19] that the normalised range defined in EN 12390-3 could not be acceptably used as a simple adaptation to the rebound indices of test locations for the estimation of the repeatability of compressive strength. For the same purpose, the spatial variation of the rebound index between multiple test locations can be considered as more promising rather than the coefficient of variation corresponding to the individual test locations (e.g. by the adaptation of variograms to depict spatial variability in geostatistics $[23,24])$. Results in this field are presented in a separate paper [25].

\section{Conclusions}

The variability of concrete strength should be recognised during the in-situ strength assessment. The rebound hammer is the most widespread method for the surface hardness testing of concrete and at the same time one of the most widespread NDT method for concrete strength estimation.

In the present paper, particular topics of the inherent variability of the rebound hammer tests are discussed. The inherent variability of the rebound hammer test corresponds to a test location and is influenced by the measurement uncertainties (operator and testing device) and the local inhomogeneity of the concrete.

Standardised precision statements are presented in terms of repeatability and reproducibility conditions both for compressive strength test and rebound hammer test.

The original L-type and N-type Schmidt hammers record the rebound index $(\mathrm{R})$ : the ratio of paths driven by the hammer mass during rebound and before impact. The new Silver Schmidt hammers, however, are implemented to record the $\mathrm{Q}$ values (coefficient of restitution). Very limited number of references can be found in the technical literature about Silver Schmidt hammer test results and according to the manufacturer there is no direct relationship between the original $\mathrm{R}$ rebound value and the new $\mathrm{Q}$ rebound value, so the relationships used earlier can not be applied for strength estimation anymore.

It can be demonstrated based on a comparative study of concrete specimens that the highest precision corresponds to the N-type original Schmidt hammer and lower precision of the L-type original Schmidt hammer and of the Silver Schmidt hammer is realised; supposedly due to the lighter hammer masses (both devices) and the sensitivity of the electro-optical recording (Silver Schmidt hammer). The uncertainty of the Q value is about $20 \%$ larger and the uncertainty of the $\mathrm{R}$ value is $50-60 \%$ larger than that of the $\mathrm{R}$ value provided by the original $\mathrm{N}$-type rebound hammer. The results confirm the long term advantageous experiences with the N-type original Schmidt hammers and the consequences of the increase in the inherent measurement uncertainty of the Silver Schmidt hammers that need future research.

A simplified reproducibility analysis of the rebound hammer test was introduced by involving three operators. Results demonstrated that the standard deviations of the measurements and particular statistical parameters of the standard deviations can be acceptable for the comparison of the uncertainty attributed different operators.

\section{Acknowledgements}

Authors gratefully acknowledge the support of the project "Development of quality-oriented and harmonized $\mathrm{R}+\mathrm{D}+\mathrm{I}$ strategy and functional model at BME" (TAMOP-4.2.1/B09/1/KMR-2010-0002), the project "Talent care and cultivation in the scientific workshops of BME" (TAMOP-4.2.2.B-10/12010-0009), the National Excellence Program "Elaborating and Operating an Inland Student and Researcher Personal Support System" (TAMOP 4.2.4. A/1-11-1-2012-0001) and the Hungarian Research Fund project "Durability and performance characteristics of concretes with novel type supplementary materials" (OTKA K 109233).

\section{References}

[1] Schmidt, E.: Rebound hammer for concrete testing (Der BetonPrüfhammer). Schweizerische Bauzeitung, 15. Juli 1950, 68. Jahrgang, Nr. 28, pp. 378-379. (in German)

[2] Shore, A. T.: Property of Hardness in Metals and Materials.Proceedings, ASTM, Vol. 11, 1911, pp. 733-739.

[3] Schmidt, E.: Quality control of concrete by rebound hammer testing (Versuche mit dem neuen Beton-Prüfhammer zur Qualitätsbestimmung des Betons). Schweizer Archiv für angewandte Wissenschaft und Technik, V. 17, Mai 1951, pp. 139-143. (in German)

[4] Greene, G. W.: Test Hammer Provides New Method of Evaluating Hardened Concrete. Journal of the American Concrete Institute, November 1954, Vol. 26, No. 3 (Title No. 51-11), pp. 249-256.

[5] Anderson, A. R, Bloem, D. L, Howard, E. L, Klieger, P, Schlintz, H. Discussion of a paper by Greene, G. W.: Test Hammer Provides New Method of Evaluating Hardened Concrete. Journal of the American Concrete Institute, December 1955, Vol. 27, No. 4, Part 2 (Disc. 51-11), pp. 256-1...256-20.

[6] Proceq SA: Non-Destructive testing of concrete - Schmidt concrete test hammer. Training course handout, October 2005, Schwerzenbach, Switzerland

[7] Proceq SA: Silver Schmidt Operating Instructions. Manual, ver 042008 , Schwerzenbach, Switzerland

[8] OECD: Glossary of Statistical Terms. Organisation for Economic Cooperation and Development, 605 p. (2008)

[9] ISO 3534-1:2006, Statistics - Vocabulary and symbols - Part 1: Probability and general statistical terms. International Standard

[10] ACI: In-Place Methods to Estimate Concrete Strength. ACI 228.1R-03, American Concrete Institute, Farmington Hills, Michigan

[11] Ermer, D. S.: Appraiser Variation in Gage R\&R Measurement. Quality Progress, 2006 May, pp. 75-78.

[12] ISO 5725-1 (1994): Accuracy (trueness and precision) of measurement methods and results - Part 1: General principles and definitions. International Organization for Standardization

[13] ASTM: Test Method for Rebound Number of Hardened Concrete.ASTM C 805/C 805M - 13, ASTM International, West Conshohocken, Philadelphia, International Standard (2013) http://dx.doi.org/10.1520/C0805_C0805M-13

[14] ASTM: Standard Practice for Preparing Precision and Bias Statements for Test Methods for Construction Materials. ASTM C 670 - 13, ASTM International, West Conshohocken, Philadelphia, International Standard (2013) http://dx.doi.org/10.1520/C0670

[15] Mommens, A.: La precision de l'estimation de la résistance du béton au moyen de l'indice sclérométrique. Matériaux et Constructions, Vol. 10, No. 55, 1977, pp. 49-54. http://dx.doi.org/10.1007/BF02473589

[16] CEN: EN 12390-3:2009, Testing hardened concrete - Part 3: Compressive strength of test specimens. European Standard (2009)

[17] Kausay, T.: Concrete - Explanation of some chapters of the concrete standard (Beton - A betonszabvány néhány fejezetének értelmezése). Magyar Mérnöki Kamara Nonprofit Kft., Budapest, 2013. (in Hungarian)

[18] Viles, H., Goudie, A., Grab, S., Lalley, J.: The use of the Schmidt Hammer and Equotip for rock hardness assessment in geomorphology and heritage science: a comparative analysis. Earth Surface Processes and Landforms, Vol. 36., pp. 320-333. (2010) http://dx.doi.org/10.1002/esp.2040

[19] Szilágyi, K., Borosnyói, A., Zsigovics, I.: Extensive statistical analysis of the variability of concrete rebound hardness based on a large database of 60 years experience. Construction and Building Materials, article in press, 2013, http://dx.doi.org/10.1016/j.conbuildmat.2013.11.113

[20] EN 13791: Assessment of in-situ compressive strength in structures and precast concrete components. European Standard (2007) 
[21] Dufour, J. M., Farhat, A., Gardiol, L., Khalaf, L.: Simulation-based Finite Sample Normality Tests in Linear Regressions. Econometrics Journal, Vol. 1, pp. 154- (1998) http://dx.doi.org/173. 10.1111/1368-423X.11009

[22] Razali, N. M., Wah, Y. B.: Power comparisons of Shapiro-Wilk, Kolmogorov-Smirnov, Lilliefors and Anderson-Darling tests. Journal of Statistical Modeling and Analytics, Vol. 2, No. 1, pp. 21-33. (2011)

[23] Clark, I.: Practical Geostatistics. Geostokos Limited, July 13, 2001, 120 p.

[24] Breysse, D., Marache, A.: Some Estimates on the Variability of Material Properties. in: Construction Reliability - Safety, Variability and Sustainability (Eds: Baroth, J., Schoefs, F., Breysse, D.), ISTE Ltd and John Wiley \& Sons, Inc., 2011. pp. 77-96.

[25] Borosnyói, A., Szilágyi, K.: Studies on the spatial variability of rebound hammer test results recorded at in-situ testing. Épitöanyag, Vol. 65, No. 4, 2013, in press, http://dx.doi.org/10.14382/epitoanyag-jsbcm.2013.19

$\underline{\text { Ref.: }}$

Katalin Szilágyi - Adorján Borosnyói - Tamás Mikó: Comparison of the inherent variability in rebound hammer tests performed with different testing instruments

Építőanyag, 65. évf. 3. szám (2013), 68-75. p.

http://dx.doi.org/10.14382/epitoanyag-jsbcm.2013.14
Különböző típusú Schmidt-kalapácsokkal végzett keménységvizsgálatok mérőhelyen belüli változékonyságának összehasonlítása

Szerkezeti betonok helyszíni roncsolásmentes szilárdságbecslésének egyikeszközea Schmidt kalapács, amely bizonyos esetekben alternatív megoldást jelenthet a kifúrt magminták vizsgálata helyett. A szerkezeti beton nyomószilárdságának változékonyságát az anyagvizsgálat illetve a szerkezettervezés során a nyomószilárdság karakterisztikus értékében vesszük figyelembe. Cikkünkben a Schmidt kalapácsos mérésbốl származó egyes mérési bizonytalansági paramétereket vizsgálunk, többféle Schmidt kalapács összehasonlításával. Rámutatunk, hogy az eredeti konstrukció alapján készült N-típusú Schmidt kalapácsok precizitása jobb, mint az L-típusú Schmidt kalapácsoké vagy a Silver Schmidt kalapácsoké. Elemezzük a Schmidt kalapácsos vizsgálat ismételhetôségi és reprodukálhatósági paramétereit is.

Kulcsszavak: beton, felületi keménység, Schmidt kalapács, mérési bizonytalanság, ismételhetôség, reprodukálhatóság

\section{Együttmúködési megállapodás}

\section{a Budapesti Múiszaki és Gazdaságtudományi Egyetem Építómérnöki Kar, Építóanyagok és Mérnökgeológia Tanszék és a Magyar Cementipari Szövetség között}

Az oktatás és az iparvállalatok nemzetközivé válása, az európai integráció, az Európai Unió tagállamaiban egységes piaci, jogi környezetre való törekvés következtében az egyes tagállamokban a felsőoktatás és a termelö vállalatok egyaránt érdekeltek a megszerzett tudás megosztásában, és ismereteik gyarapításában. Ez a közös szemlélet a gyártástechnológiákon túl különösen az új fejlesztésű építőanyagok, alapanyagok, azok felhasználása, beépítése, annak technológiája, a környezetvédelmi és jogi környezet, a szabványos vizsgálatok és a kutatás-fejlesztés területén kölcsönös előnyt biztosítanak a képzési intézmény és az iparág számára.

Ezzel összefüggésben a BME Építőmérnöki Kar, Építőanyagok és Mérnökgeológia Tanszék és a Magyar Cementipari Szövetség (MCSZ) megállapodnak abban, hogy a kutatás-fejlesztés valamint a felsőfokú szakemberképzés, szakmérnök képzés, és az ahhoz kapcsolódó tevékenységek területén együttmüködésbe kezdenek. Az együttműködés kölcsönös bizalmon és egymás szaktudásának és szakértelmének elismerésén alapszik. A közös kezdeményezést a Felek lépésről lépésre fejlesztik, és alakulását figyelemmel kísérik. $\mathrm{Az}$ együttmüködésben az oktatási intézmény részéröl a Tanszék oktatói, a Szövetség részéről tagjainak szakemberei vesznek részt. $\mathrm{Az}$ együttműködés létrehozásával további cél még az oktatási rendszerből kikerülő, frissen végzett szakemberek versenyképes, naprakész, azéppen alkalmazott technikai színvonalnak, szabályozási környezetnek megfelelő tudáshoz és tapasztalathoz segítése.

Az Együttmüködési megállapodás alapját képezi kutatás-fejlesztési feladatokban való együttműködéseknek, pályázatokban való közös részvételeknek, valamint az ipari szakembereknek a bekapcsolódását különféle oktatási formákba. Mindezek szolgáljáka Felekhatékonyabb és eredményesebb müködését, valamint az oktatásban részt vevő hallgatók naprakész tudáshoz, míg az iparvállalatok felkészült szakemberekhez való jutását.

Budapest, 2013. július 17.

\section{Cooperation agreement}

between the Budapest University of Technology and
Economics, Faculty of Civil Engineering, Department
of Construction Materials and Engineering Geology
and the Hungarian Cement Association

Higher education institutes and industrial partners in the countries of the European Union are interested in sharing the available knowledge with each other and the further progress in science and education; due to the European integration, the international cooperation and the integrated legal and market regulations within the EU. This common viewpoint provides advantages to both parties in $R+D$ through the development of novel construction materials and production technologies, basic materials, installation and use of materials, environmental protection techniques, standard testing methods and the harmonisation of the legal environment.

The BME Faculty of Civil Engineering, Department of Construction Materials and Engineering Geology and the Hungarian Cement Association (MCSZ) agrees to start a cooperative work in the fields of $R+D$, top level professional education, post-graduate professional education and connected areas. The cooperation is based on the common trust and the recognition of the technical knowledge and practical skills of each other. The common initiative is going to be monitored and developed by the two participating parties together. Participating members of the contribution are university lecturers and researchers from BME and professionals from the members of MCSZ. Distinguished aim of the cooperation is to accommodate graduate students receiving their BSc or MSc degree with up to date knowledge and experience to become competitive, high standard professionals ready to use their knowledge and skills in the actual technical and legal environment of the building construction industry.

The treaty is expected to be a basis of further $R+D$ cooperation, participation in grant applications and can provide possibility for professionals in practice to join to the different levels of higher education. The efforts can serve a more effective operation of the participating parties, to have graduate students accommodated with up to date knowledge and to provide industrial partners with skilled professionals.

Budapest, 17 July 2013

$\begin{array}{ccc}\text { Dr. György L. Balázs } & \text { Dr. László Dunai } & \text { János Szarkándi } \\ \text { Head of dept. } & \text { Dean } & \text { President } \\ \text { BME Faculty of Civil Engineering } & M C S z\end{array}$

